pieces of rock abrade and po'ish and scratch tha rocky bed in which they lie when they are dragged over it by the moving ice. Without this motion they can of course effect nothing either as burnishers or as excavators.

This motion has been shown by recent experiments to be very largely if not entirely a differential $m$ stion due to the visc us nature of ice, as Forbes long ago argued on à priori an 1 other grounds that it was. The viscosity of ice is different at different temperatures. It differs also greatly when it is in th: form of granulated ice, such as a glacier is composed of, from ice formed in a laboratory or directly frozen from water in a pond, but in any case it is slight, and it needs a considerable and a long-applied force to make it shear. The consequence is that when it rests on a level or nearly level surface, where gravity does not work, it ceases to move at all. In order that it should acquire motion sufficient to drag stones, \&c., along, it is necessary that there should be some vis a tergo. Either the ice must rest on a slope sufficiently inclined to generate a gravitating movement in it, as a whole, or the slope of its upper surface must be sufficiently great to cause the movement of its surface layers to be continued down to and to remain effective in its nethermost parts. Every attempt made by Croll and others to invent for, and assign to, ice molecular movements capable of causing lateral motion in the stones beneath it other than those induced by gravity, seems to me to have utterly failed. The cause-the only cause which is competent to make it move is gravity acting either in one or the other way above specified.

This seens to be the inevitable conclusion whenever the problem is tested as it ought to be tested, by empirical tests. If so, it seems to put out of court the continual appeals made to ice as the distributor of debris over hundreds of miles of level plains, and as the excavator of basins and lakes at a considerable distance from mountain slopes.

In the first place, the modulus of cohesion of ice being what it is, it has been shown by Mallet, Oldham, and Irving that thru it cannot be conveyed through it for more than a short distance, since it must yield and eventually crush.

This à priori view is supported by the actual observation of glaciers in which we find that the rate of motion is very largely a function of the slope of the bed, and when a glacier leaves the slope on which it rests and gets on to level ground it very soon ceases to move altogether.

It has been argued that in the Ice Age the ice was piled up in dome-shaped ice sheets, and that the distribution of the boulders and the excavation of mountain lakes was due to the results of the efforts of the viscous mass to reach a state of equilibrium by hydrostatic movement, or by rolling over itself. But this ignores the very slight viscosity of ice which would require a very high slope in its upper layers to induce movement in its lower ones at all. It is impossible to see how this high slope could be secured, since the effort to restore equilibrium would be continuous, and the potential movement involved in every fresh fall of snow would at once be dissipated instead of being accumulated.

I cannot see, therefore, how under any circumstances it is possible for ice either to travel over long distances of level ground, or to excavate hollows such as the great majority of mountain lakes are.

I have not in this letter referred to the ge logical difficulties of such an hypothesis, which are manifold. I have limited myself to the physical difficulties alone. They seem to me to underlie the whole problem, and it is useless to discuss it until they have been solved, yet they are persistently ignored by the ardent champions of ice. That ice can ds a good deal when allied with gravity is true enough, but the problem, as presented by Mr. Wallace, Prof. Jaines Geikie and others requires that it should continue to do portentous work when no longer allied with gravity. Is it too much to ask that some justification should be offered (and nowhere better than in your catholic page;) for such an en rrmous unverified postulate?

Athenæum Club, July $\mathbf{I}$. HENRY H. HowORTH.

\section{Abnormal Weather in the Himalayas.}

ON May 26 I walked from Changla Gali (about 9000 feet) to Dungar Gali (under 9000 feet) by the "pipe" road. On the way we passed (the road is cut along the side of the steep mountains) a narrow valley filled with snow to about a height of 100 feet. The width of the hard snow on the road was 20 feet. On the 28 th I walked back to Changla Gali by the main road.
Here we saw a great deal of snow. A bridge spanned a narrow valley, a mass of flat snow, perhaps i 5 feet thick, filled the valley to the bridge. No snow ran up the valley. Then we came on two valleys converging into one at the point where the road passed. B th valleys above and the valley below were filled with snow, and the road for I 50 feet was cut on the face of the snow.

In the first week of Miy terrific storms burst over Murree we had onstant storms at Dingar on the night of the 26 th up to $12 \mathrm{a} . \mathrm{m}$. on the day of our leaving, the $28 \mathrm{th}$. O.1 the 28 th the last t 10 miles of the road into Changla were simply carpeted with leaves and twigs broken off by a violent hailstorm. The side; of the road, sometimes the road itself (four hours after the storm), were covered with drift and massed hailstones of the size of big marbles (ice with the usual whitish centre).

Thi; continuance of sno $v$ and this stormy weather is stated to be alto rether abnormul.

Cirangla Gali, May 29.

\section{Peculiar Hailstones.}

A FRIEND of mine writes me from Peshawar about a very curious phenomenon which I think is worth notice in your columns. The monsoon has set in this season earlier than for some years past. A few days ago in a village named Daduzai (a tehsil in the Peshawar district) rain fell, precedel by a wind storm, and with the rain came a shower of hailstoass which lasted for a few minutes. The most curious part of this occurrence is that the hailstones when touched were not at all cold, and when put in the mouth (as is the custom in this hot coun'ry) tasted like sugar. I am further told that these hailstones were extremely fragile, and as so on as they reached the ground they broke in pieces. These pieces when examined looked like broken sticks of crystallised nitre. My informant tasted them, and was struck with their purity and sweetness. A few pieces were also sent to the Diputy Commissioner of the district. The phenomenon has been duly reported in the lead. ing newspapers of the province, and the $A k \hbar b a r-i-A m$ has noted it in its leading columns.

KAN HAIYALAL.

Lahore, June 20.

\section{Crocodile's Egg with Solid Shell.}

DURING the year 1885 I was stationed at Trincomalee, when it was my luck to find a large crocodile's egy near $\mathrm{K}$ intalay tank. On showing the specimen to several friends who knew more about natural history than I did, they expressed their astonishment at seeing a nard-shelled egg, as the c sncensus of opinion was that such eggs were invariably surrounded with a soft parchment-like covering.

$I$ made a hole in the tnp and bottom of the exg and blew out the contents. The shell is still in my possession, and resembles more the hard enamelled-like egg of the ostrich than anything else I have seen.

The above facts may interest those who take a pleasure in objects of natural history.

Murree Hills, June 7 . J. BAtTersby.

\section{UNIVERSITY AND EDUCATIONAL ENDOW. $M E N T$ IN AMERICA.}

THE statements in the following extract are so remarkable that I think they deserve a wider publicity than they will probably receive in the pages of a Parliamentary paper.

One may hope that the reconstructed University of London will make provision for post-graduate study and the advancement of knowledge in the greatest city of the world. It must be admitted that this cannot be done without the expenditure of a good deal of money. May one hope further that the cause of the higher education will find friends amongst us in London as munificent as university and technological studies have found in one of the newest of the world's cities?

Kew, June 30.

W. T. THiselton-Dye R.

No. I 237 , voL. 48 ] 